\title{
The Credit Channel in a Small, Open Economy
}

(Preliminary and incomplete; not for citation; comments welcome)

December 22, 2006

\begin{abstract}
Previous research on the credit channel has focused on the US, a large economy in which external linkages are relatively small. Our paper appears to be the first to investigate the credit channel in a small, open economy. Using a structural VAR, we examine the evidence for the conventional "closed economy" and open economy monetary transmission mechanisms - as well as for a credit channel. The data provides support for the conventional "closed economy" and open economy transmission mechanisms - as well as evidence that suggests a role for the credit channel in a small, open economy. An additional contribution of our paper is to analyze the sources of credit market shifts in the wake of a monetary policy shock.
\end{abstract}

Keywords: monetary policy, transmission mechanism, credit channel, open economy macroeconomics

JEL codes:

Professor Huntley Schaller, Carleton University and Institute for Advanced Studies (Vienna)

Sadaquat Junayed, Carleton University

Mailing Address:

Department of Economics

Carleton University

1125 Colonel By Drive

Ottawa ON Canada K1S 5B6

Email: Schaller: schaller@ccs.carleton.ca, Junayed: jsadaquat@yahoo.com

Tel: Schaller: (613) 520-3751, Junayed: (613) 520-2600 ext. 1442

The authors thank seminar participants at the conference on Small, Open Economies in a Globalizing World (Rimini, Italy) and Carleton University for helpful comments.

Schaller thanks the SSHRC for financial support. 


\section{Introduction}

According to the conventional account of the monetary policy transmission mechanism, a contractionary monetary policy shock raises the nominal interest rate. Due to nominal rigidities, this raises the real interest rate. An increase in the real interest rate reduces the interest-sensitive components of aggregate spending. This shifts the aggregate demand curve to the left, reducing both real output and the nominal price level.

A substantial literature examines whether there is an additional credit channel for monetary policy. Two possible channels have been explored. The first is the broad credit channel, which works through balance sheet effects. The second is the narrow credit channel, sometimes also referred to as the bank lending channel. This paper is about the broad credit channel.

At times, the credit channel is discussed as if it were a distinct, free-standing alternative to the conventional channel. This may not be the most useful way to think about the credit channel. Instead, it may be more useful to think of the credit channel as a series of mechanisms which amplify and propagate the conventional interest rate effects of monetary policy. According to credit channel theory, the direct effects of monetary policy are amplified by endogenous changes in the external finance premium. Monetary policy pushes the external finance premium in the same direction as the interest rate.

Monetary policy affects firms' balance sheets in at least three ways. First, a contractionary monetary policy shock affects balance sheets directly by increasing interest expense (and thus decreasing the amount of internal finance available to firms). Second, contractionary monetary policy tends to decrease asset prices and thus the value of collateral. This is also a direct effect. Third, contractionary monetary policy indirectly 
affects firms' balance sheets by decreasing demand and thus decreasing revenue (and internal finance). Although it is straightforward to analytically delineate these effects, it is an open question as to whether they make a quantitatively important difference to the monetary policy transmission mechanism.

Bernanke and Gertler (1995) document four sets of stylized facts about monetary policy. Their focus is on a large economy (the US) in which external linkages play a relatively small role. Their first stylized fact is that monetary policy has a transitory effect on the interest rate but a persistent effect on real output and the nominal price level. Second, final demand falls quickly in the wake of a contractionary monetary policy shock, but output falls more slowly, implying that inventories increase in the first quarter or two after a monetary-policy-induced increase in the interest rate. Third, early, sharp declines in final demand occur in residential investment and consumption. Fourth, business fixed investment declines after the initial interest rate shock has largely dissipated.

To a first approximation, these stylized facts seem consistent with the conventional story. The slow response of nominal prices is consistent with the idea that monetary policy affects the short-term real interest rate, even though monetary policy operates directly through the nominal interest rate. The declines in residential investment and business fixed investment are consistent with the idea that the increase in the real interest rate, induced by monetary policy, affects interest-sensitive components of aggregate spending.

There are puzzles with the conventional story, though. The first might be referred to as the "magnitude puzzle". Small changes in the nominal interest rate seem to have 
large effects on real variables. But much empirical research on specific components of output (e.g., business fixed investment) suggests that the interest rate has relatively small effects. ${ }^{1}$

The second puzzle might be called the "timing puzzle". The change in the nominal interest rate induced by a monetary policy shock is transitory. For example, Bernanke and Gertler (1995) find that the interest rate is largely back to its initial level in three quarters. On the other hand, the peak effect of monetary policy on some components of spending occurs later. For example, the peak effect on business fixed investment occurs after the increase in the interest rate has largely dissipated. In fact, the poor correspondence in timing between interest rate movements and quantity movements in components of spending, such as business fixed investment, may help explain why it has traditionally been hard to find strong cost-of-capital effects. ${ }^{2}$

The third puzzle might be referred to as the "composition puzzle". Monetary policy affects the short-term interest rate. It should therefore have the largest effect on short-lived assets. But the biggest effects of monetary policy are usually on investment, particularly fixed investment. ${ }^{3}$

The contribution of this paper is to examine the credit channel in a small, open economy. Surprisingly, this appears to be the first paper to examine the credit channel in

\footnotetext{
${ }^{1}$ See, e.g., the survey by Chirinko (1993) on business fixed investment and the survey by Ramey and West (1999) on inventory investment.

${ }^{2}$ This is consistent with recent evidence showing that the relationship between the capital stock and the real interest rate is stronger in the long run than at business cycle frequencies. See Caballero $(1994,1999)$ and Schaller (2006) on equipment capital and Maccini, Moore, and Schaller (2004) on the stock of inventories. All of these papers argue that high-frequency dynamics make it difficult to discern the long-run relationship between the interest rate and the capital stock using econometric techniques that emphasize high-frequency variation in the data.

${ }^{3}$ All of these puzzles are documented by Bernanke and Gertler (1995).
} 
a small, open, industrialized economy. ${ }^{4}$ Our approach is to begin by examining whether the stylized facts hold in a small, open economy. ${ }^{5}$ The specific country we focus on is Canada. We expand our focus beyond the "closed economy” transmission mechanism, examining the conventional open economy monetary policy transmission mechanism and checking to see how well it corresponds with the empirical evidence.

In the literature on the credit channel, there has been an extensive debate about whether movements in the quantity of credit are due to shifts in credit supply or credit demand. There is a strong theoretical basis for skepticism about interpreting a decrease in the quantity of credit as evidence for the credit channel. For example, a negative demand shock might lead firms to lower their expectations about future demand and correspondingly scale back their investment projects. With less investment demand, firms might need to borrow less, leading to a leftward shift of the demand for credit. Similarly, an adverse technology shock might lead households to lower their expectations of permanent income. Depending on the aggregate time profile of consumption and labour income and the rate of time preference, among other factors, this might lead to a decrease in household credit demand.

In contrast, the credit channel involves a leftward shift in credit supply (due to balance sheet effects, such as the reduction in collateral, that make financial intermediaries less willing to lend at a given interest rate). ${ }^{6}$ It has proved difficult to

\footnotetext{
${ }^{4}$ There is a literature on the "balance sheet effect" in developing countries, but this is quite a different issue.

5 This is not the first paper to examine the effects of monetary policy in a small, open economy. See, e.g., Sims (1992), Cushman and Zha (1997), and Kim and Roubini (2000). None of these papers, though, examines the credit channel.

${ }^{6}$ Here we focus on the simplest example, which involves the shift in a conventional supply curve, but there are other possibilities that could result in credit channel effects. For example, the reduction in internal finance could tighten constraints on finance-constrained households or firms, leading to an increase in the
} 
provide evidence on whether a reduction in the quantity of credit was due to a shift in credit supply, rather than demand. ${ }^{7}$

Our contribution is to introduce two new approaches to distinguishing between shifts in credit demand and credit supply. The first is based on using both prices and quantities. While shifts in credit supply and demand have the same implication for the quantity of credit, they have opposite implications for the price of credit.

The second is based on the reaction in domestic and foreign markets to a contractionary monetary policy shock. If there is a shift in credit demand - due, for example, to lower expectations of product demand and scaled-back investment projects it should affect credit demand by domestic firms both in the domestic credit market and in the foreign market. On the other hand, a monetary policy shock in a small economy will have a negligible effect on credit supply in a large economy. Thus, if the quantity of credit for domestic firms falls in both the domestic and foreign market, it provides evidence of a shift in credit demand. If the quantity of credit for domestic firms falls in the domestic market but remains unchanged in the foreign market, it provides evidence of a shift in a domestic credit supply curve.

The paper is organized as follows. Section 2 presents the identifying assumptions for the structural VAR and briefly describes the data. Section 3 presents the stylized facts that are relevant to the "closed economy" transmission mechanism. Section 4 presents evidence on the conventional open economy transmission mechanism. Section 5 discusses how we use price and quantity movements to identify credit market shifts.

shadow cost of external finance (and the external finance premium). Stiglitz and Weiss (1981) provide a model of another possibility - a backward-bending loan supply curve.

${ }^{7}$ One of the best pieces of evidence comes from Peek and Rosengren (1997), who use data on Japanese banks to distinguish shifts in credit demand by American firms from shifts in the supply of credit by Japanese banks. 
Section 6 shows how we use domestic and foreign markets to identify credit market shifts. Section 7 provides a summary and conclusion.

\section{Empirical Methodology and Data}

To estimate the effect of monetary policy on the economy, we use a structural vector autoregression (Structural VAR or SVAR). Our identifying assumptions involve the contemporaneous coefficient matrix and can be summarized in the following equation that links the reduced-form errors to the structural shocks.

$$
\left[\begin{array}{l}
e_{P} \\
e_{Y} \\
e_{M} \\
e_{i} \\
e_{s} \\
e_{\mathrm{WP}} \\
e_{F F R} \\
e_{o}
\end{array}\right]=\left[\begin{array}{cccccccc}
1 & g(P, Y) & 0 & g(P, i) & 0 & g(P, W P) & 0 & 0 \\
0 & 1 & 0 & g(Y, i) & 0 & g(Y, W P) & 0 & 0 \\
g(M, P) & g(M, Y) & 1 & g(M, i) & 0 & 0 & 0 & 0 \\
g(i, P) & g(i, Y) & g(i, M) & 1 & g(i, s) & g(i, W P) & g(i, F F R) & 0 \\
g(s, P) & g(s, Y) & g(s, M) & g(s, i) & 1 & g(s, W P) & g(s, F F R) & g(s, o) \\
0 & 0 & 0 & 0 & 0 & 1 & 0 & 0 \\
0 & 0 & 0 & 0 & 0 & g(F F R, W P) & 1 & 0 \\
0 & 0 & 0 & g(o, i) & 0 & 0 & 0 & 1
\end{array}\right]\left[\begin{array}{l}
u_{P} \\
u_{Y} \\
u_{M} \\
u_{i} \\
u_{s} \\
u_{W P} \\
u_{F F R} \\
u_{o}
\end{array}\right]
$$

where the $e_{j}$ represent the structural disturbances and the $u_{j}$ represent the residuals in the reduced form VAR equations, $\mathrm{P}$ is the price level, $\mathrm{Y}$ is output, $\mathrm{M}$ is money, $\mathrm{i}$ is the interest rate (overnight rate), $\mathrm{s}$ is the exchange rate (\$CAN/\$US), WP is the world price of commodities (commodity price index in \$US), FFR is the Fed funds rate, and o is the “Other” variable.

The first and second equations represent the domestic goods market. We allow output to affect the price level contemporaneously, as a recursive representation of a standard, textbook AD-AS system. In addition, we allow supply shocks and monetary 
policy shocks to have a contemporaneous effect. We assume that other variables affect the domestic goods market only with a lag. ${ }^{8}$

The third and fourth equations represent demand and supply in the money market. The third equation represents money demand, which is assumed to depend contemporaneously on the interest rate, the price level, and income. This is the standard assumption in the literature. The fourth equation represents the monetary policy reaction function. We assume that the domestic central bank (Bank of Canada) sets the interest rate after observing the current values of money, the price level, output, the exchange rate, the world price of oil, and the foreign interest rate. ${ }^{9}$

The fifth equation involves the exchange rate. Since the exchange rate is a forward-looking variable that evolves continuously through time, we allow shocks to all the other variables to affect the exchange rate contemporaneously.

The sixth equation involves world prices. We treat world commodity prices as exogenous (at least contemporaneously), an appropriate assumption for a small, open economy.

The seventh equation represents US monetary policy. We treat US monetary policy as being exogenous to domestic variables in the Canadian economy (at least contemporaneously). Again, this seems like an appropriate assumption for a small, open economy. We do, however, allow supply shocks to influence US monetary policy contemporaneously, an assumption that is symmetric with our assumption that supply

\footnotetext{
${ }^{8}$ Exchange rate shocks may well have an effect on the domestic goods market, but the literature on the Jcurve suggests that the effect of changes in the exchange rate on quantities (the volume effect) involves a lag of several months, so we maintain the assumption that $\mathrm{g}(\mathrm{P}, \mathrm{s})=\mathrm{g}(\mathrm{Y}, \mathrm{s})=0$.

${ }^{9}$ These assumptions are less restrictive than those of many papers in the literature. We allow monetary policy to respond contemporaneously to more variables for two reasons. First, we want to ensure that we capture monetary policy shocks, rather than the endogenous reaction of monetary policy to supply or other shocks. Second, our less restrictive assumptions reflect the fact that we are using quarterly data, while many papers use monthly data, where more restrictive assumptions may be more appropriate.
} 
shocks may enter the Bank of Canada’s monetary policy reaction function contemporaneously.

Finally, we include one "Other” variable in each VAR. The purpose of including a single additional variable in the VAR is to maintain the VAR at a manageable size, while allowing us to examine the response of many different variables to monetary policy shocks. A similar strategy has been used by Bernanke and Gertler (1995) and Christiano, Eichenbaum, and Evans (1996), among others. In calculating the main impulse response functions, the "other" variable is business fixed investment. As is the case for output, we assume that the interest rate can affect business fixed investment within the quarter but restrict the contemporaneous response of business fixed investment to other variables to zero. Allowing supply shocks to affect business fixed investment makes little difference to the impulse response functions.

We examined the robustness of the results to the relaxation of some other restrictions. In particular, the impulse response functions are very similar if we allow the interest rate to be contemporaneously affected by business fixed investment. Again, the impulse response functions are very similar if we allow supply shocks to affect business fixed investment and allow business fixed investment to enter the contemporaneous monetary policy reaction function.

To satisfy the order condition, $\mathrm{N}(\mathrm{N}-1) / 2$ restrictions are required to identify the structural VAR using the contemporaneous coefficient matrix, where $\mathrm{N}$ is the number of variables in the VAR. The foregoing assumptions imply 33 zero restrictions, so we have 5 overidentifying restrictions. 
In all cases, we include four lags of the variables in the VAR. The only identifying assumptions involve zero restrictions on the contemporaneous coefficient matrix. We impose no restrictions on lagged coefficients. The confidence bands are based on 10,000 replications (using RATS software).

We use Canadian data for the period 1980:1-2004:4. Because we examine components of expenditure, we must use quarterly, rather than monthly, data. Our sample is the longest time period for which we were able to obtain all the necessary data.

\section{The “Closed Economy” Stylized Facts}

In a closed economy, the conventional transmission mechanism works through the effect of monetary policy on interest-sensitive components of domestic spending, such as investment. To distinguish this mechanism from the effects that work through the exchange rate and net exports (the conventional open economy transmission mechanism), we refer to the effects through the interest-sensitive components of domestic spending as the “closed economy” mechanism.

Figure 1 shows the impulse response function of the interest rate to a contractionary monetary policy shock. The central line shows the impulse response function. The other two lines are the 95\% confidence band. Consistent with the stylized facts for the US (a large economy in which imports and exports constitute a relatively small fraction of GDP), monetary policy in Canada has a transitory effect on the interest rate. By two quarters after the shock, the interest rate is close to its pre-shock level and no longer significantly higher. 
Figure 2 shows the effect of a contractionary monetary policy shock on the price level and output. Monetary policy clearly has a persistent effect on both the price level and output, an effect that lasts much longer than the increase in the interest rate.

Figure 3 shows the impulse response function for final demand. Final demand falls quickly and exhibits a hump-shaped pattern.

Figure 4 shows the impulse response functions for residential investment, consumption, and business fixed investment. The peak effect on both types of investment occurs about four quarters after the monetary policy shock. Thus, the peak effect occurs after the effect on the interest has largely dissipated.

In summary, in Canada, a small open economy, as in the US, a large economy, the conventional account of the monetary policy transmission mechanism largely fits the facts. However, the same key puzzles that we discuss in the introduction - magnitude puzzle, timing puzzle, and composition puzzle - are also present.

\section{The Conventional Open Economy Channel}

According to the conventional account, in an open economy, a contractionary monetary policy shock increases the interest rate. This tends to induce capital inflows, which put upward pressure on the domestic currency. Under a floating exchange rate regime, the domestic currency tends to appreciate. In the very short run, this increases net exports (due to the value effect). Over time, the appreciation of the domestic currency tends to decrease the competitiveness of the economy, leading to a drop in net exports. 
Figure 5 shows the impulse response function of the exchange rate, which is measured as Canadian \$/US \$. A contractionary monetary policy shock quickly leads to an appreciation of the Canadian dollar.

Figure 6 shows the effect of a contractionary monetary policy shock on net exports. The classic J curve is evident. There is a slight increase in net exports in the very short run due to the value effect. Over time, the competitiveness of domestic products is affected and net exports fall.

The stylized facts for the Canadian economy correspond well to the conventional analysis of the effects of monetary policy in an open economy.

\section{Using Price and Quantity to Identify Credit Market Shifts}

Many credit markets shrink after a contractionary monetary policy shock. According to the advocates of a credit channel, it may represent a decrease in credit supply. Disentangling shifts in credit demand and credit supply has been one of the most controversial areas in debates about the credit channel.

We use a new approach to distinguishing between shifts in credit demand from shifts in credit supply. Our approach is based on simple economics and illustrated in Figure 7, where r represents the real interest rate (the price of credit) and $\mathrm{L}$ represents the quantity of credit. If the demand curve for credit shifts to the left, the quantity of credit decreases, as does the interest rate. If the supply of credit shifts to the left, the interest rate rises. $^{10}$

\footnotetext{
${ }^{10}$ In the Stiglitz-Weiss (1981) model of credit rationing, it is possible that the interest rate might remain constant if the market was initially rationed, in which case the interest rate might remain at the point of inflection of the backward-bending credit supply curve.
} 
A structural VAR provides a way of analyzing the movements of price and quantity in response to a shock, specifically a monetary policy shock. To the best of our knowledge, ours is the first paper to use a structural VAR to examine the joint movements of the price and quantity of credit.

Figure 8 shows the movements in price and quantity for consumer loans. The interest rate on consumer loans clearly rises in response to a contractionary monetary policy shock. The increase in the interest rate on consumer loans is highly significant in the initial quarters after the shock. The quantity of consumer loans begins to fall shortly after a contractionary monetary policy shock. The decrease in quantity is significant for several quarters after the monetary policy shock. The data point to a shift in the supply curve for consumer loans in the wake of a contractionary monetary policy shock.

Figure 9 provides corresponding impulse response functions for residential mortgages. Again, a contractionary monetary policy shock significantly increases the interest rate on residential mortgages. The quantity of residential mortgage loans also falls in the wake of a contractionary monetary policy shock. Again, the decrease is significant for several quarters and suggests a leftward shift in the supply of mortgage loans.

For firms, previous research in corporate finance has suggested that trade credit is one of the most important sources of finance for small, young firms (and, more generally, for the firms that are the most likely to suffer from finance constraints). ${ }^{11}$ We therefore begin by examining the reaction of trade credit to monetary policy. Unfortunately, there does not appear to be any aggregate data on the interest rate on trade credit. However, previous firm-level studies have documented that the nominal interest rate on trade credit

${ }^{11}$ See, e.g., Petersen and Rajan (1994). 
is essentially constant at business cycle frequencies. ${ }^{12}$ Since economic theory (and the impulse response function plotted in Figure 2) suggest that contractionary monetary policy lowers inflation, this implies that the real interest rate on trade credit rises in the wake of a contractionary monetary policy shock. Figure 10 plots the impulse response function for trade credit. There is a clear decline in trade credit in the quarters following a contractionary monetary policy shock. The decline is highly significant for many quarters.

A reasonable concern about trade credit is that it is a limited source of funds, important perhaps for very small firms that may not account for a large proportion of aggregate output. To date, we have been unable to obtain comparable interest rate and quantity data for many other forms of credit that are relevant for firms. We have, however, been able to obtain data on both price and quantity for corporate bonds. Figure 11 plots the price and quantity impulse response functions. A contractionary monetary policy shock raises the interest rate on corporate bonds. The interest rate is above its preshock level for many quarters after the shock. The difference between the pre-shock and post-shock corporate interest rate is significant and persistent. The same is true for the quantity of corporate bonds, which declines quickly after a contractionary monetary policy shock and remains significantly below its pre-shock level for many quarters. Since the corporate finance literature suggests that bond issues are primarily available to relatively large, well established firms, the results in Figure 11 suggest that the credit channel may be important not only for very small firms but also for large firms.

\footnotetext{
${ }^{12}$ See, e.g., Ng, Smith, and Smith (1999).
} 


\section{Using Domestic and Foreign Markets to Identify Shifts}

If monetary policy in a small economy leads to a shift in credit demand, it should show up in the quantity of credit associated with domestic borrowers in both the domestic market and in the foreign market. In contrast, if monetary policy leads to a shift in credit supply, it should show up in the domestic market but not in a large foreign market.

Because of the close integration between the Canadian and US economies, the relevant foreign credit market for Canadian firms is the US market. We have been able to obtain data on bond issues by Canadian non-financial businesses in the US. Figure 12 plots the impulse response functions for bond issues in Canada and in the US. In Canada (as we have seen in Figure 11), there is a substantial, significant, and persistent decline in bond issues in the wake a contractionary monetary policy shock. In the US market, there is little evidence of a significant decline in bond issues by Canadian firms.

\section{Conclusion}

The goal of this paper is to examine whether there might be a credit channel in a small, open economy. Previous research on the credit channel has focused exclusively on the US, a large economy in which external linkages play a relatively small role in the macroeconomy (as measured, for example, by the ratios of imports and exports to output).

We find evidence of the same stylized facts about the effects on monetary policy in Canada that previous research has documented for the US. These stylized facts are broadly consistent with the conventional "closed economy" monetary transmission mechanism in which an increase in the nominal short interest rate translates into an 
increase in the long real interest rate (due, in part, to nominal rigidities) and thereby affects interest-sensitive components of aggregate demand, such as residential investment.

Bernanke and Gertler (1995) argue that, although the key stylized facts are broadly consistent with the conventional transmission mechanism, they highlight three important puzzles - about the magnitude, timing, and composition of monetary policy and suggest that the credit channel complements the conventional monetary policy transmission mechanism by helping to amplify and propagate the conventional interest rate effects. To the extent that this is true, the fact that the same stylized facts emerge in Canada suggest that the credit channel may also play an important role in a small, open economy.

We go beyond the existing large, "closed economy" evidence by looking at the conventional open economy monetary policy transmission mechanism, in which an increase in the nominal short interest rate leads to capital inflows and appreciation of the domestic currency and therefore - over time - leads to a reduction in net exports. We find that a contractionary monetary policy shock is, indeed, followed by an appreciation of the Canadian dollar and an eventual decrease in net exports.

The evidence therefore seems consistent with: 1) the conventional "closed economy" transmission mechanism; 2) the stylized facts cited in support of a credit channel that augments the conventional "closed economy" mechanism; and 3) the conventional open economy mechanism.

We go beyond these stylized facts in an effort to distinguish the source of credit market shifts in the wake of a monetary policy shock. Leftward shifts in both credit 
demand and credit supply reduce the quantity of credit, but a leftward shift in credit demand lowers the interest rate, while a leftward shift in credit supply increases the interest rate. By using a structural VAR, we are able to map out the reactions of the interest rate and the quantity of credit to a monetary policy shock. In a variety of credit markets - both household and firm credit markets - we find evidence of a leftward shift in credit supply.

We use a second approach to distinguishing the sources of credit market shifts, an approach based on the idea that shocks in a small economy can affect that economy but will not affect global markets. Specifically, if a contractionary monetary policy shock shifts credit demand by domestic borrowers to the left, the quantity of credit associated with domestic borrowers will decline both in the domestic and foreign credit market. In contrast, if a contractionary monetary policy shock shifts domestic credit supply, the quantity of credit associated with domestic borrowers will decline in the domestic credit market, but not in the foreign credit market. Using data on bond issues by Canadian firms and a structural VAR, we find a substantial, significant, and persistent decline in the quantity of bonds issued in Canada but little evidence of a significant decline in bond issues by Canadian firms in the US market. 


\section{References}

Bernanke, Ben S., and Mark Gertler, "Inside the Black Box: The Credit Channel of Monetary Policy Transmission,” Journal of Economic Perspectives, Fall 1995, 9(4), pp. 27-48.

Caballero, Ricardo J., "Small Sample Bias and Adjustment Costs," Review of Economics and Statistics, February 1994, 76(1), pp. 52-58.

Caballero, Ricardo J., “Aggregate Investment,” in John B. Taylor and Michael Woodford (eds.), Handbook Of Macroeconomics, vol. 1B, Amsterdam: Elsevier North Holland, 1999, pp. 813-862.

Chirinko, Robert, "Business Fixed Investment Spending: Modeling Strategies, Empirical Results, and Policy Implications,” Journal of Economic Literature, December 1993, 31(4), pp. 1875-1911.

Christiano, Lawrence J., Martin Eichenbaum, and Charles Evans, "The Effects of Monetary Policy Shocks: Some Evidence from the Flow of Funds," Review of Economics and Statistics, February 1996, 78(1), pp. 16-34.

Cushman, David O., and Tao Zha, "Identifying Monetary Policy in a Small Open Economy Under Flexible Exchange Rates,” Journal of Monetary Economics, August 1997, 39(3), pp. 433-448.

Kim, Soyoung, and Nouriel Roubini, "Exchange Rate Anomalies in the Industrial Countries: A Solution with a Structural VAR Approach,” Journal of Monetary Economics, June 2000, 45(3), pp. 561-586.

Maccini, Louis J., Bartholomew J. Moore, and Huntley Schaller, "The Interest Rate, Learning, and Inventory Investment," American Economic Review, December 2004, 94(5), pp. 1303-1327.

Ng, Chee K., Janet Kiholm Smith, and Richard L. Smith, "Evidence on the Determinants of Credit Terms Used in Interfirm Trade,” Journal of Finance, June 1999, 54(3), pp. 1109-1129.

Peek, Joe, and Eric S. Rosengren, "The International Transmission of Financial Shocks: The Case of Japan,” American Economic Review, September 1997, 87(4), pp. 495-505.

Peek, Joe, and Eric S. Rosengren, "Unnatural Selection: Perverse Incentives and the Misallocation of Credit in Japan," American Economic Review, September 2005, 95(4), pp. 1144-1166. 
Peterson, Michell A., and Raghuram G. Rajan, “The Benefits of Lender Relationships: Evidence from Small Business Data,” Journal of Finance, March 1994, 49(1), pp. 3-37.

Ramey, Valerie A., and Kenneth D. West, "Inventories," in John B. Taylor and Michael Woodford (eds.), Handbook of Macroeconomics, vol. 1B, Amsterdam: North Holland, 1999, pp. 863-923.

Schaller, Huntley, 2006, “Estimating the Long-Run User Cost Elasticity,” Journal of Monetary Economics, May 2006, 53(4), pp. 725-736.

Sims, Christopher A., "Interpreting the Macroeconomic Time Series Facts: The Effects of Monetary Policy,” European Economic Review, June 1992, 36(5), pp. 975-1011.

Stiglitz, Joseph, and Andrew Weiss, “Credit Rationing in Markets with Imperfect Information,” American Economic Review, June 1981, 71(3), pp. 393-410. 
Figure 1

Interest Rate

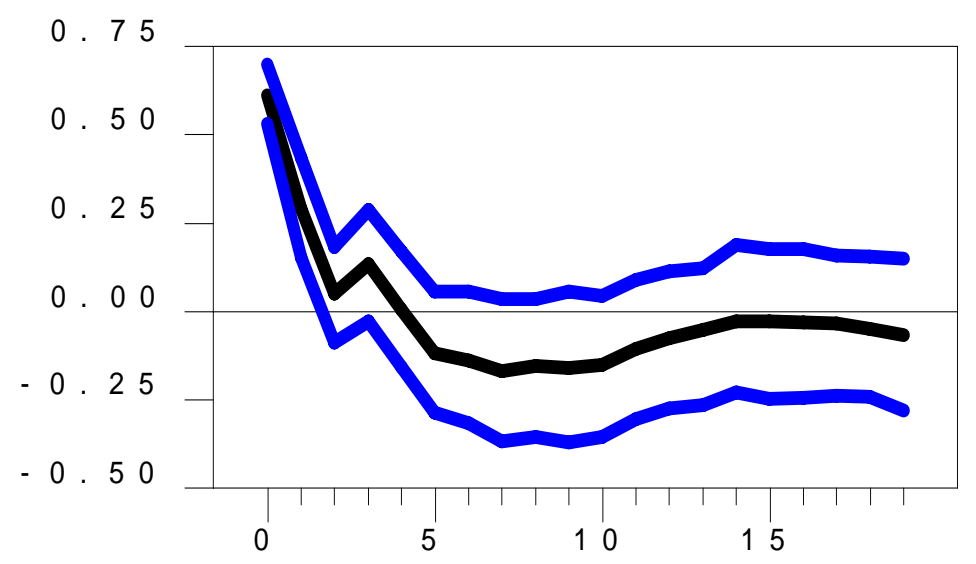


Figure 2

Price Level

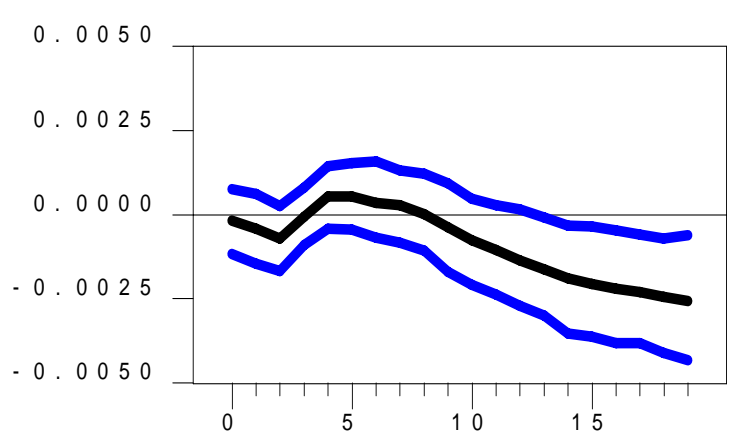

Output

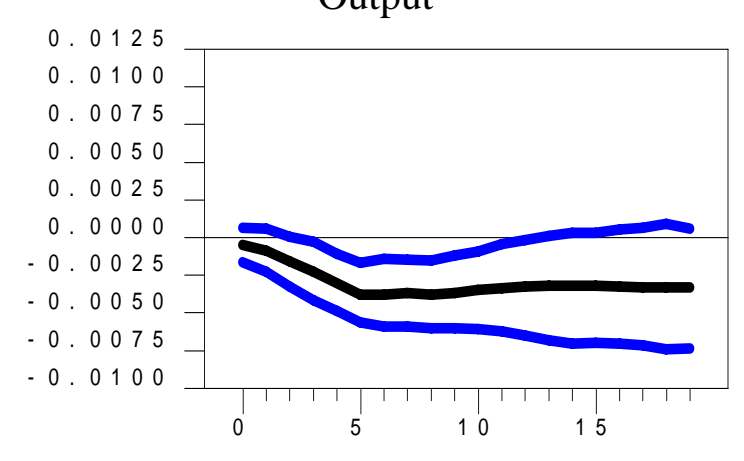


Figure 3

Final Demand

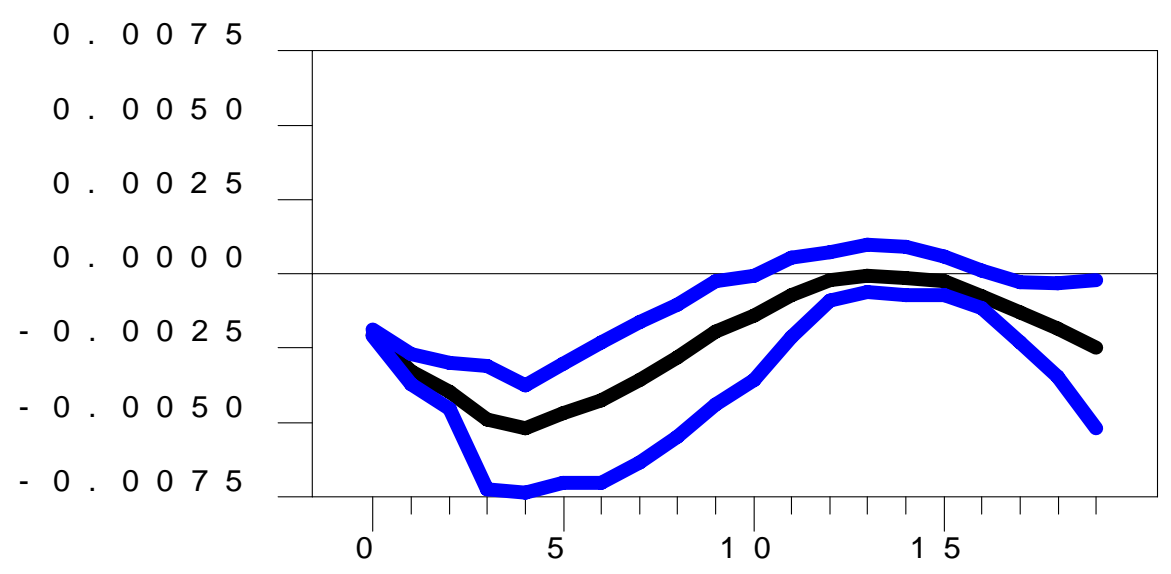




\section{Figure 4}

\section{Residential Investment}

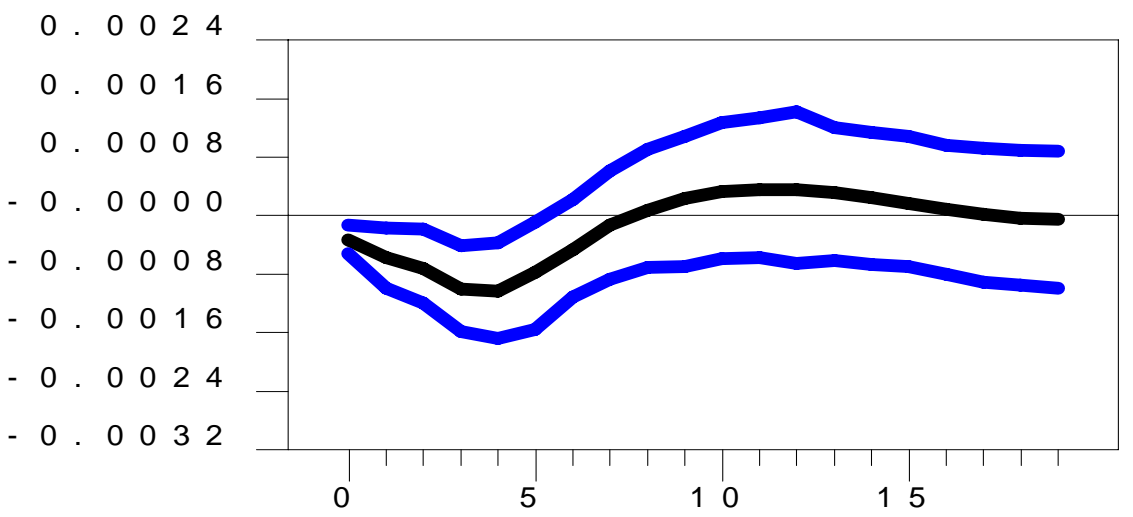

Consumption

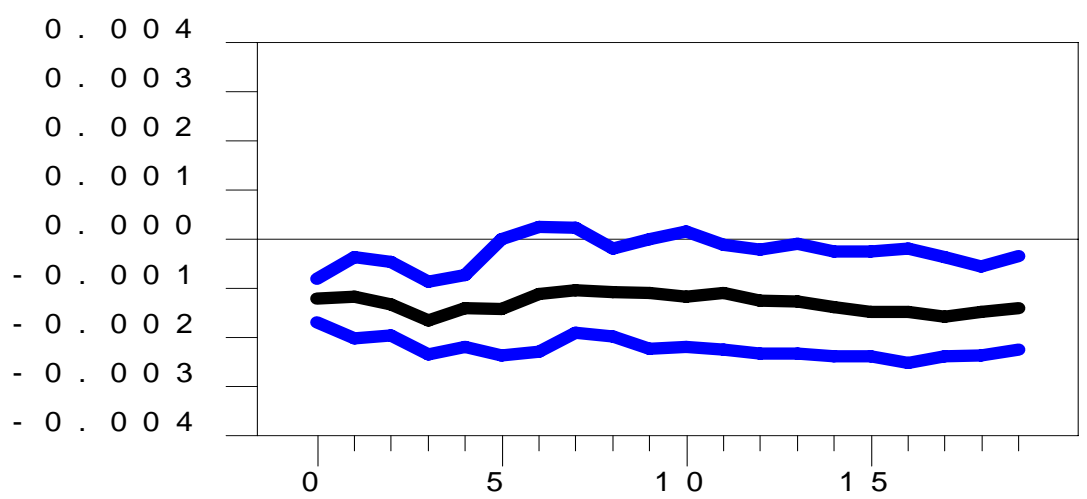

Business Fixed Investment

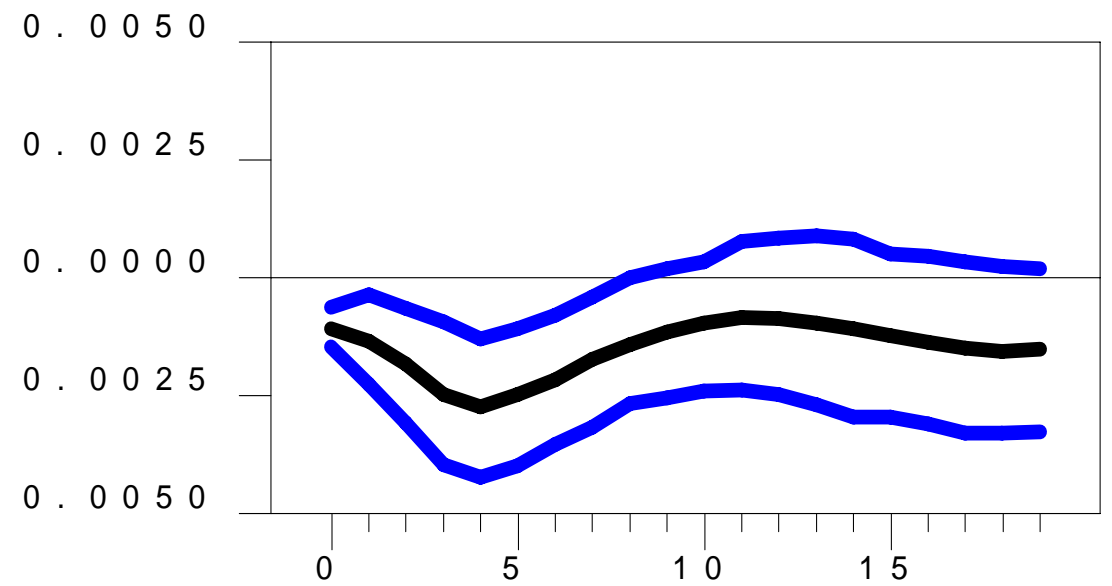


Figure 5

Exchange Rate

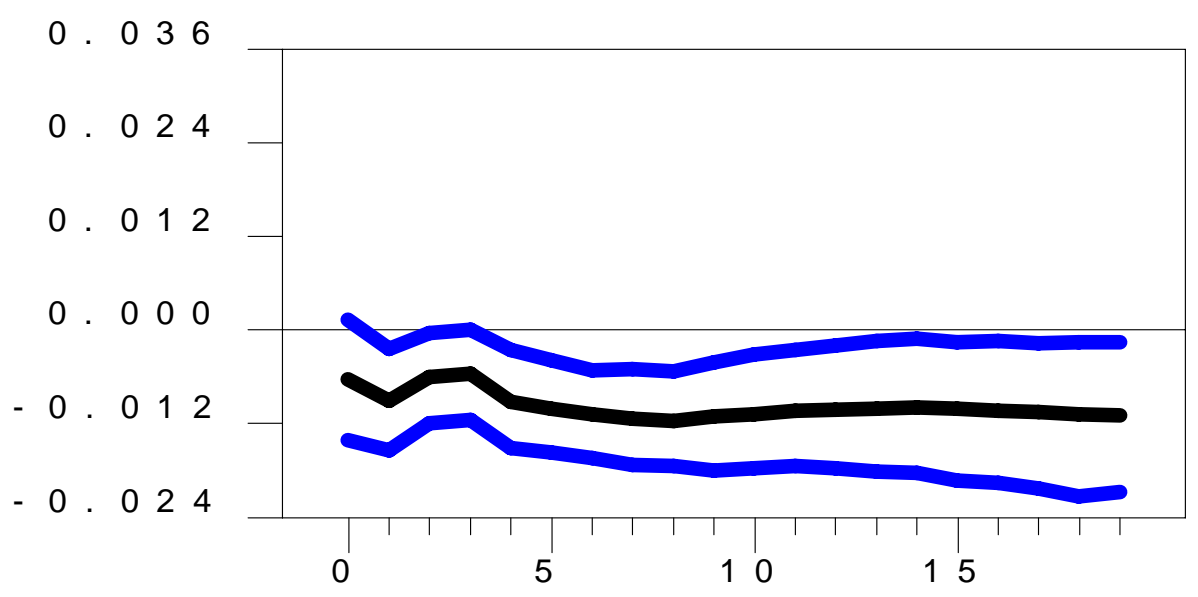


Figure 6

Net Exports

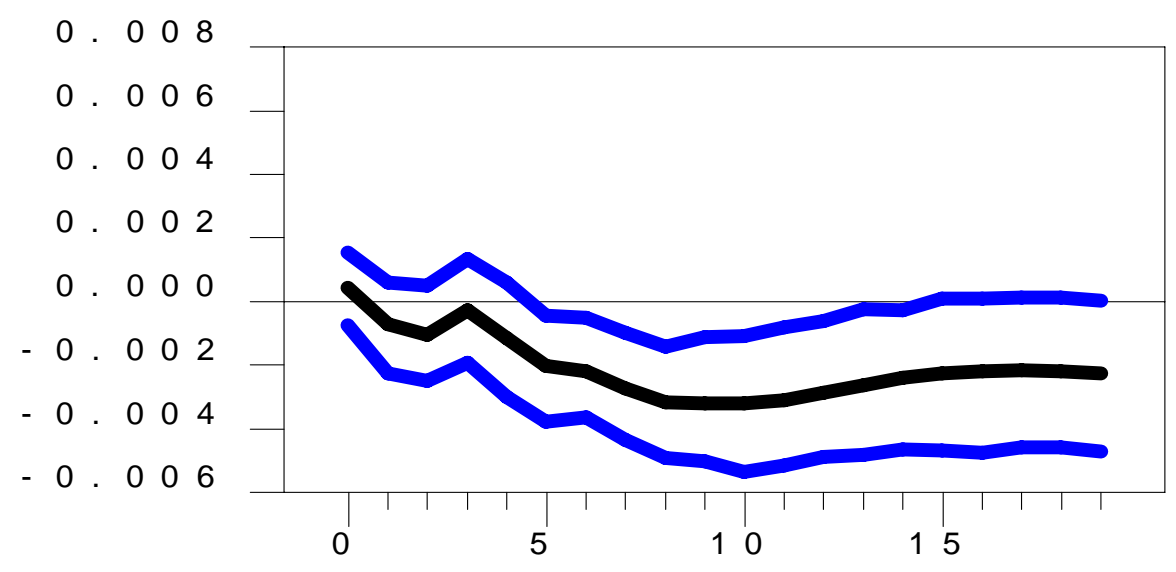


Figure 7

Shifts in Credit Supply and Credit Demand
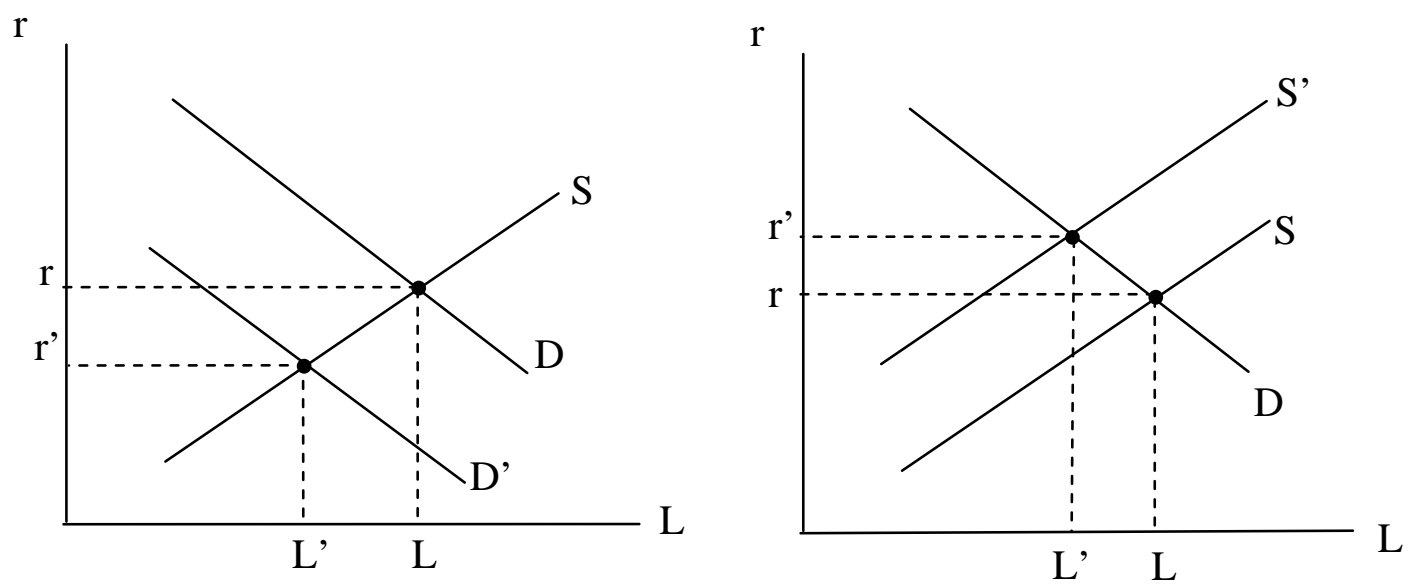
Figure 8

Consumer Loans
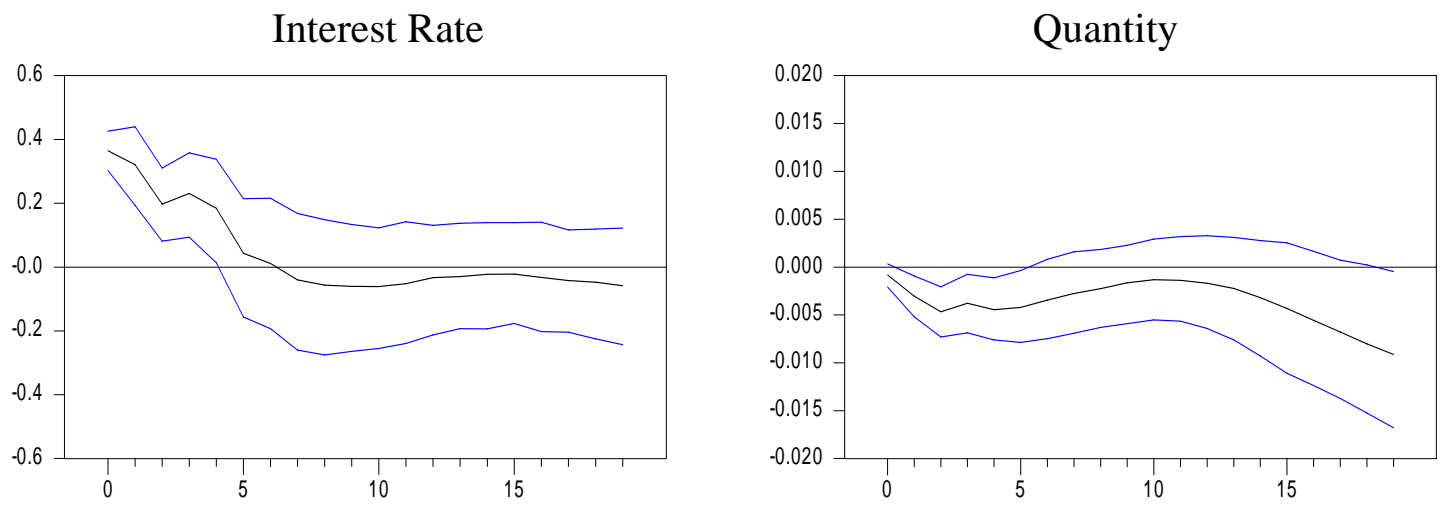
Figure 9

Residential Mortgage Loans
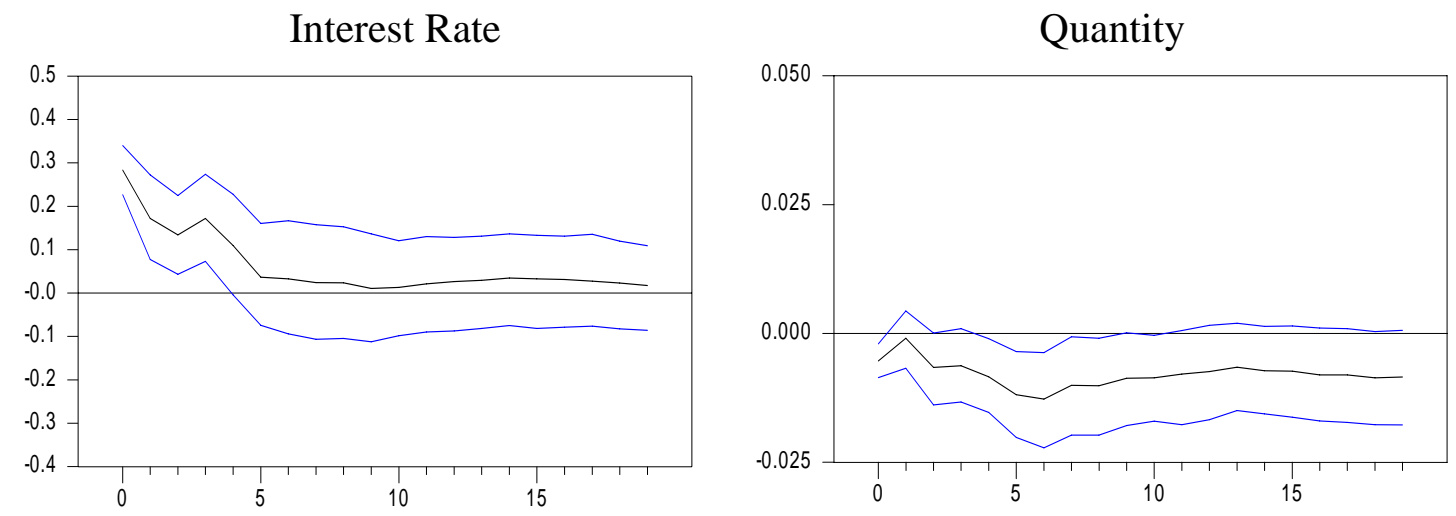
Figure 10

Trade Credit

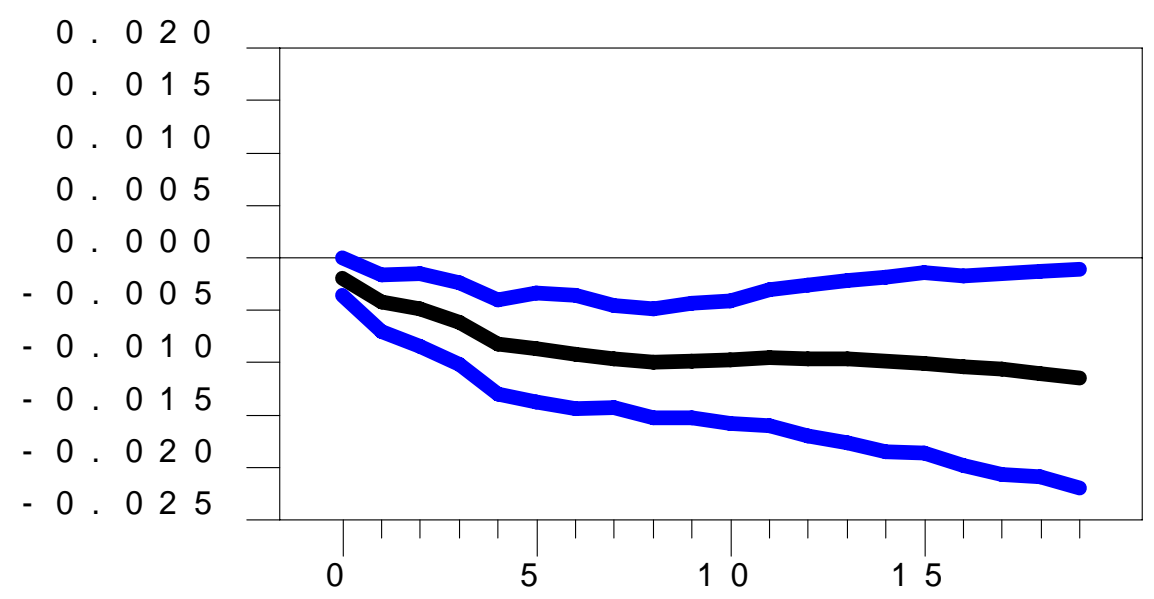


Figure 11

Corporate Bonds
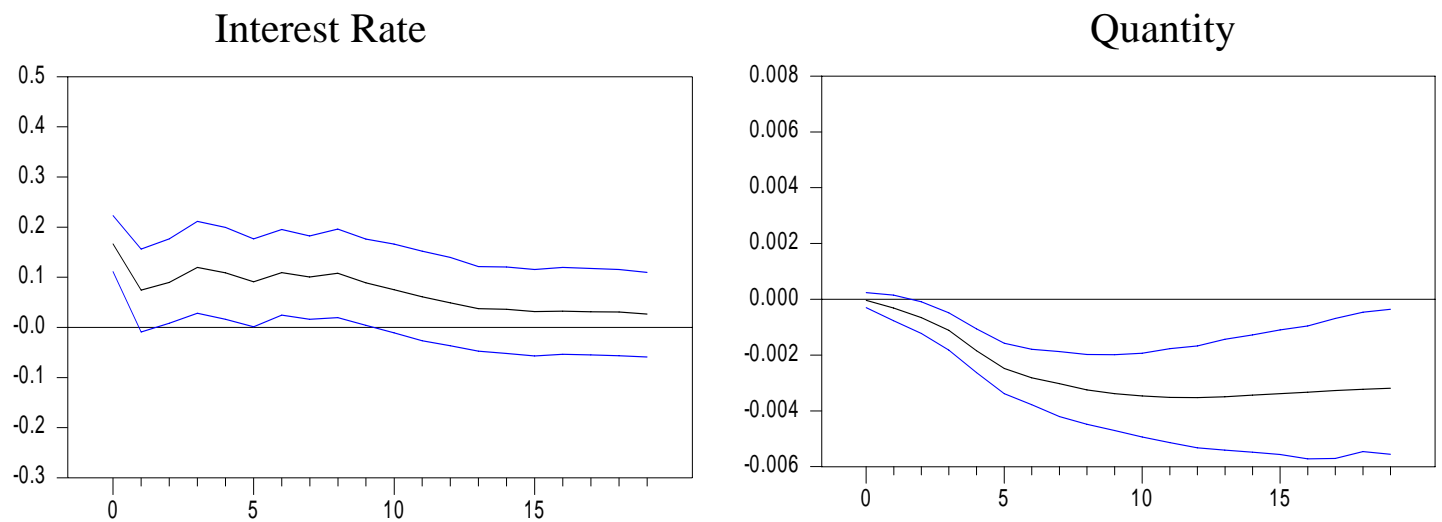
Figure 12

Bond Issues (by Canadian, non-financial businesses)
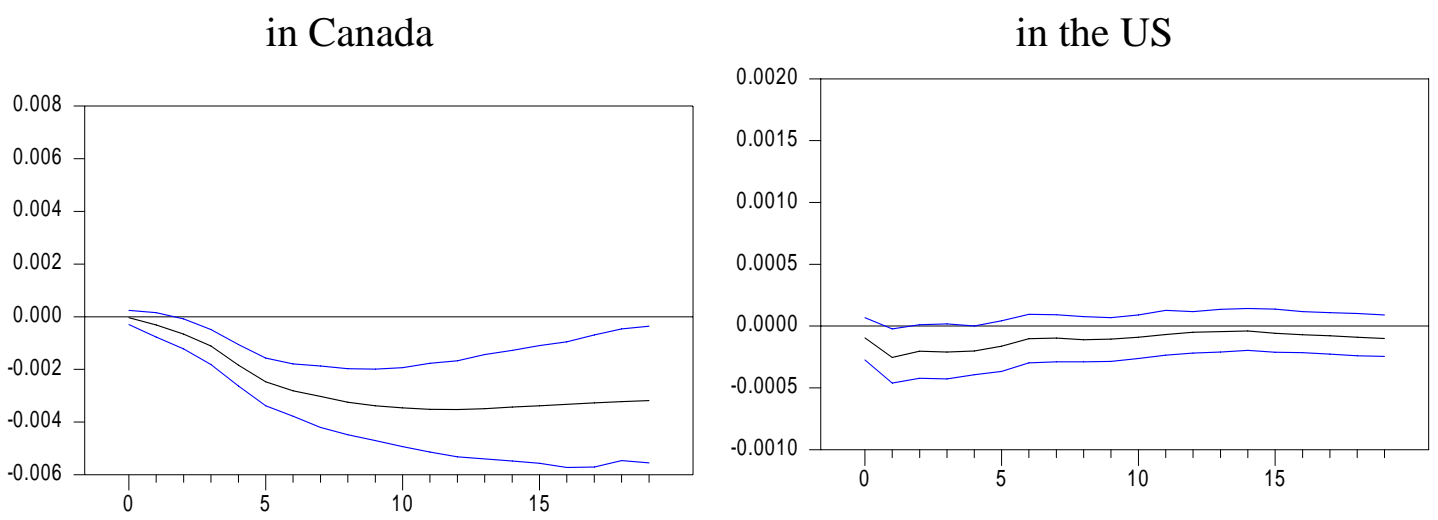